\title{
Evaluation of the Quality of Life of Clients with Chronic Ischemic Pain
}

\author{
Débora Fernanda Amaral Pedrosa ${ }^{1}$ \\ Andressa Karina Amaral Plá Pelegrin ${ }^{2}$ \\ Hilze Benigno de Oliveira Moura Siqueira ${ }^{3}$ \\ Talita de Cássia Raminelli da Silva ${ }^{4}$ \\ Orlando Carlos Gomes Colhado ${ }^{5}$ \\ Fátima Aparecida Emm Faleiros Sousa ${ }^{6}$
}

\begin{abstract}
The evaluation of quality of life (QOL) faced with chronic ischemic pain involves the clients in their subjectivity and multidimensionality. This descriptive study aimed to evaluate the quality of life of clients who presented chronic ischemic pain. A total of 100 clients of hospital institutes participated in the study. The instrument used to assess pain was an 11 point numerical scale, and to assess the quality of life, the World Health Organization Quality of Life-abbreviated questionnaire. The arithmetic mean for chronic pain was $5.59 \pm 3.16$ points. The means for quality of life were: in

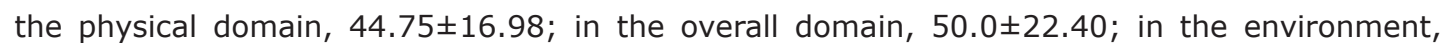
$55.06 \pm 13.51$, in the psychological, $56.21 \pm 17.19$ and in the social domain, $68.33 \pm 21.84$. Thus, the physical domain was, among the areas analyzed, the one which presented a greater impact on the quality of life of the clients with chronic ischemic pain.
\end{abstract}

Descriptors: Pain; Ischemia; Quality Of Life; Evaluation; Arterial Occlusive Diseases.

\footnotetext{
${ }^{1}$ RN, M.Sc. in Nursing, Professor, Universidade de Uberaba, MG, Brazil. E-mail: amaraldf@yahoo.com.br.

${ }^{2}$ RN, M.Sc. in Nursing, Escola de Enfermagem de Ribeirão Preto, Universidade de São Paulo, WHO Collaborating Centre for Nursing Research Development, SP, Brazil. E-mail:andressapelegrin@yahoo.com.br.

${ }^{3}$ Psychologist, Doctoral Student in Nursing, Escola de Enfermagem de Ribeirão Preto, Universidade de São Paulo, WHO Collaborating Centre for Nursing Research Development, SP, Brazil. E-mail: hilze@bol.com.br.

${ }^{4}$ Nursing undergraduate student, Escola de Enfermagem de Ribeirão Preto, Universidade de São Paulo, WHO Collaborating Centre for Nursing Research Development, SP, Brazil. Scholarship holder of the Scientific Initiation Program at the Conselho Nacional de Desenvolvimento Científico e Tecnológico (CNPq). E-mail: talitac_girl@yahoo.com.br.

${ }^{5}$ Physician, Ph.D. in Medical Sciences, Adjunct Professor, Departamento de Medicina, Universidade Estadual de Maringá, PR, Brazil. E-mail: orlandocolhado@uol.com.br.

${ }^{6}$ RN, Ph.D. in Nursing, Full Professor, Escola de Enfermagem de Ribeirão Preto, Universidade de São Paulo, WHO Collaborating Centre for Nursing Research Development, SP, Brazil. E-mail: faleiros@eerp.usp.br.
}

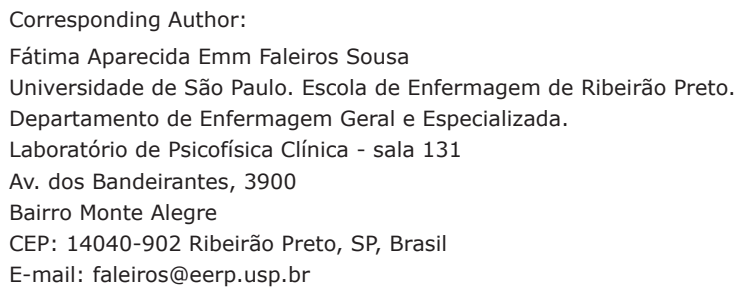




\section{Avaliação da qualidade de vida em clientes com dor crônica isquêmica}

A avaliação da qualidade de vida (QV), frente à dor crônica isquêmica, envolve o cliente na sua subjetividade e multidimensionalidade. Este estudo descritivo teve como objetivo avaliar a qualidade de vida de clientes que manifestaram dor crônica isquêmica. Participaram da pesquisa 100 clientes de instituições hospitalares. O instrumento aplicado para avaliar a dor foi a escala numérica de 11 pontos e, para a qualidade de vida, o questionário World Health Organization Quality of Life-abreviado. A média aritmética para a dor crônica foi de $5,59 \pm 3,16$ pontos. As médias para a qualidade de vida foram:

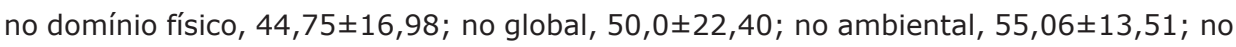

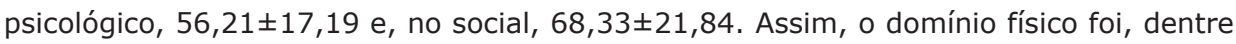
os domínios analisados, o que apresentou maior impacto sobre a qualidade de vida dos clientes com dor crônica isquêmica.

Descritores: Dor; Isquemia; Qualidade De Vida; Avaliação; Arteriopatias Oclusivas.

\section{Evaluación de la calidad de vida en clientes con dolor crónico isquémico}

La evaluación de la calidad de vida (CV) frente al dolor crónico isquémico debe considerar la subjetividad del cliente y las múltiples dimensiones envueltas. Este estudio descriptivo tuvo como objetivo evaluar la calidad de vida de clientes que manifestaron dolor crónico isquémico. Participaron de la investigación 100 clientes de instituciones hospitalarias. El instrumento aplicado para evaluar el dolor fue la escala numérica de 11 puntos y para la calidad de vida, el cuestionario World Health Organization Quality of Life abreviado. EI

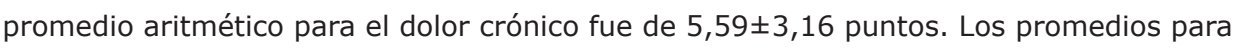
la calidad de vida fueron: en el dominio físico, 44,75 $\pm 16,98$; en el global, $50,0 \pm 22,40$; en

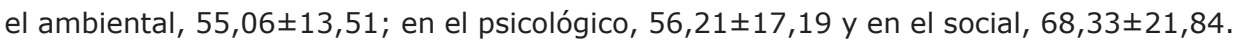
Así, el dominio físico fue, entre los dominios analizados, el que presentó un mayor impacto sobre la calidad de vida de los clientes con dolor crónico isquémico.

Descriptores: Dolor; Isquemia; Calidad de Vida; Evaluación; Arteriopatías Oclusivas.

\section{Introduction}

In Brazil, the characterization of the quality of life of patients suffering from chronic pain as a consequence of peripheral vascular diseases, such as Peripheral Arterial Disease (PAD), is an underexplored area of study. By conducting a search for articles in the Scientific Electronic Library Online database - SciELO Brazil, using the keyword "quality of life" (subject), 654 articles were found, however, refining the search using the keyword "Peripheral Arterial Disease" (subject) obtained the a result "no article". A separate search on SciELO, with the keyword "Peripheral Arterial Disease" (subject) yielded five published articles. By including the keyword "pain" (subject), no articles were found on the subject. Searching the Theses Bank of the Coordination for the Improvement of Higher Education PersonnelCAPES, with the keyword "quality of life" (exact term), 7453 records of dissertations and theses were found, but with the inclusion of the keyword "pain" the results were reduced to 45 records and adding the keyword "Peripheral Arterial Disease", the result of the search was "no record".

Peripheral Arterial Disease is caused by obstruction of the artery feeding the affected limb, usually affecting people aged over 55 years, leading to tissue ischemia and the most common symptom for this disease, intermittent claudication, characterized by the sensation of pain, cramps and fatigue, which limit the ability to walk. Peripheral Arterial Disease affect the physical 
capacity and quality of life of its sufferer, however, with the treatment of the symptoms, their health status may improve(1-2).

The perception of pain is unique, personal, subjective and exclusive to each human being and is influenced by sensory, affective, cognitive, social and behavioral factors ${ }^{(3)}$. The duration of pain is an important aspect to evaluate the impact on the quality of life (QOL) of millions of people suffering from chronic pain ${ }^{(4)}$. According to the World Health Organization (WHO), "one in five people suffers from chronic pain of moderate to severe intensity and one in three is unable to maintain independent living due to the pain"(5).

The definition of QOL suggested by the WHO is "the individual's perception of their position in life in the context of the culture and value systems in which they live and in relation to their goals, expectations, standards and concerns"(6). Each client can assign a unique meaning to their perception of $\mathrm{QOL}$, which is constructed, deconstructed and reconstructed according to the situations and experiences. Quality of Life has a multidimensional character, in which the clients are considered in terms of their physical, psychological and social aspects, and constantly interact with the environment where they live ${ }^{(7)}$. With regard to theory and practice, there are six main characteristic that are implicated in the QOL: the subjectivity, the phenomenon, the multidimensionality, the experimental evaluation, the dynamics, and the ability to evaluate and quantify it. The characteristic of being subjective implies that the individual is the only reliable source for an evaluation of $\mathrm{QOL}^{(4)}$.

According to the $\mathrm{WHO}$, the generic instruments World Health Organization Quality of Life-100 (WHOQOL100) and WHOQOL-BREF measure the impact of disease on the QOL of people and can be used in clinical trials or epidemiological studies, since they facilitate the comprehension of the diseases and the developing of new treatments. These instruments are of great importance for establishing the baseline score of QOL and serve to monitor changes throughout the interventions performed $^{(6)}$

Each domain of the WHOQOL-BREF consists of subdomains. The physical domain consists of seven subdomains: pain and discomfort; energy and fatigue; sleep and rest; mobility; activities of daily living; dependence on medicinal substances and medical aids; and work capacity. The psychological domain consists of six subdomains: positive feelings; thinking, learning, memory and concentration; self-esteem; bodily image and appearance; negative feelings; and spirituality/religion/ personal beliefs. The social domain is composed of three sub-domains: personal relationships; social support; and sexual activity. Finally, the environment domain is composed of eight sub-domains: physical safety and security; home environment; financial resources; health and social care - availability and quality; opportunities to acquire new information and skills; participation in, and opportunities for recreation/leisure activities; physical environment - pollution / noise / traffic / climate; and transport ${ }^{(8)}$. The choice of the generic instrument WHOQOL-BREF to evaluate QOL in this study is justified to measure the multidimensional and subjective variables that involve the perception of well-being in the human being(8). Thus, pain might influence the health status and QOL of people in relation to their family affection, their psychological state and their cultural, economic and environmental aspects. Therefore, the aim of this study was to evaluate the QOL of clients with complaints of chronic ischemic pain.

\section{Method}

This was a descriptive cross-sectional study with a non-probability sample, of the accidental type. It was conducted at the Clinical Hospital, School of Medicine of Ribeirão Preto- University of São Paulo (HCFMRP-USP) and in the Teaching Hospital of the Triângulo Mineiro Federal University (HE-UFTM) in Uberaba in 2008. Initially, study participants were selected through medical records in order to identify those who were suffering from PAD. In the next step, those who complained of acute pain, patients with diabetes mellitus and rheumatic diseases, those with no ability to rationalize and without the physical and/or cognitive skills to participate were excluded and 100 clients who complained of chronic pain (existing for more than three months) were selected to participate in this study. The study was approved by the Research Ethics Committee of the HCFMRP-USP (protocol no 10595/2007) and the participants were informed and signed the Terms of Free Prior Informed Consent. Then, the data related to sociodemographic indicators (age, gender, marital status, education level, occupation and income) were recorded on a sheet in the form of a checklist.

Two instruments were applied, an 11-point numeric scale (ranging from 0 to 10 ) for pain evaluation and the generic instrument WHOQOL-BREF to evaluate QOL. For the measurement of chronic ischemic pain, the category estimation method was used. Each participant 
has to choose a number corresponding to the amount of perceived pain through a numerical scale graded from 0 to 10 (11-point scale). The task required of the participant was to assign a value between "zero", which corresponded to the absence of pain, and "ten" the worst possible pain in the last twenty-four hours, noting that the participant could choose scores one, two, three, four, five, six, seven, eight and nine, which meant intermediate amounts of pain.

For the evaluation of the QOL, the method of category estimation was used, in which the participants judged each question about their QOL using the last two weeks as the reference. Among the generic instruments for evaluation of the quality of life, the WHO developed the World Health Organization Quality of Life, known as the WHOQOL100 , composed of one hundred questions and divided into six domains. The abbreviated version of WHOQOL100 is known as the WHOQOL-BREF, which consists of specific instructions for its completion, two questions address the overall quality of life (one on the perception of QOL and the other on the perception in relation to the health condition) and 26 questions correspond to the four specific domains - Physical, Psychological, Social and Environment. This instrument was translated and validated for the Portuguese language ${ }^{(8)}$.

Each question of the WHOQOL-BREF has a Likert type scale ranked with alternatives ranging from one to five ("very dissatisfied" to "very satisfied"; "not at all" to "completely" and "not at all" to "extremely"). The points obtained are transformed into a scale of zero to one hundred, in order to establish comparisons between the domains, and the higher the value for each domain, the better the quality of life ${ }^{(6,8)}$. The mean of the score for overall quality of life and of the scores of the quality of life for each domain - physical, psychological, social and environment - were calculated using the Statistical Package for the Social Sciences (SPSS) 16.0 for Windows, following the syntax described in the WHOQOL-BREF.

\section{Results}

The sample obtained was composed of 100 participants with mean age of $64.83 \pm 12.14$ years, $67 \%$ were male, $54 \%$ married, $18 \%$ widowed, $14 \%$ divorced, $7 \%$ for both of the categories single and stable union, most of them, $58 \%$ had incomplete elementary schooling and $63 \%$ reported being retired, with an average income of 1.78 minimum wages. In analyzing the pain phenomenon, most (15 participants) assigned the value 10 (mode) for the intensity of chronic ischemic pain, which corresponds to the worst pain perceived, and the arithmetic mean was $5.59 \pm 3.16$ points.

Regarding QOL, it was found that none of the participants failed to answer the questions of the WHOQOL-BREF. It was identified that the physical domain, composed of seven sub-domains, obtained the lowest mean, amounting to $44.75 \pm 16.98$, followed by the overall quality of life with a mean of $50.0 \pm 22.40$, environment domain (eight sub-domains) 55.06 \pm 13.51 , the psychological domain (six sub-domains) $56.21 \pm 17.19$ and for the social domain (three sub-domains), which obtained the highest average, 68.33 \pm 21.84 . The complete results of the descriptive analysis for each domain are presented in Table 1.

Table 1 - Quality of life of clients with chronic ischemic pain in the interior of São Paulo State and in the Triângulo Mineiro, 2008. $(n=100)$

\begin{tabular}{|c|c|c|c|c|c|c|}
\hline Domains of WHOQOL-abbreviated & Mean & Standard deviation & Median & Minimum & Maximum & Mode \\
\hline Physical domain & 44.75 & 16.98 & 46.43 & 7.14 & 96.43 & 57.14 \\
\hline Psychological domain & 56.21 & 17.19 & 54.17 & 4.17 & 100.00 & multiples \\
\hline Social domain & 68.33 & 21.84 & 66.67 & 16.67 & 100.00 & multiples \\
\hline Environment domain & 55.06 & 13.51 & 56.25 & 18.75 & 87.50 & 62.50 \\
\hline Overall quality of life & 50.00 & 22.40 & 50.00 & 0.00 & 100.00 & 62.50 \\
\hline
\end{tabular}

\section{Discussion}

Pain negatively affects the majority of QOL dimensions, with the physical, psychological, level of independence and health environment domains of the WHOQOL-100 being the most affected ${ }^{(4)}$. The four domains of WHOQOL-BREF explained $36.1 \%$ of the overall quality of life of 211 elderly patients with a mean age of $71.09 \pm 8.09$ years, with the physical domain being the one that most contributed with $28.2 \%$, followed by the environment domain with $6.2 \%$, the psychological with $1.3 \%$ and the social with $0.4 \%{ }^{(9)}$. In the present study, the physical domain was the most affected, followed by environment, psychological and social. 
For both environment and psychological domains very similar means were obtained.

In the literature, a study was found that applied the WHOQOL-BREF in 20 patients undergoing hemodialysis treatment at a specialized clinic. The physical domain (which includes the sub-domains of pain and discomfort, energy and fatigue, sleep and rest) was the most affected and presented the lowest mean, 64.28, ranging between a maximum 92.86 and a minimum of 25 and is the domain that most influences the quality of life; closely followed by the environment domain which presented a mean of 64.69 (maximum 84.38 and minimum of 40.63); the social domain which presented an mean of 70.83 (maximum 100 and minimum of 41.67 ) and the psychological domain with a mean of 76.46 (maximum 100 and minimum of 37.5$)^{(10)}$. Another study on QOL, in which there was an application of the WHOQOL-bref involving 220 people (average age $56.22 \pm 12.9$ years) with chronic non-transmissible disease (cardiovascular, endocrine, musculoskeletal and pulmonary) and 220 healthy people (mean age $49.3 \pm 12.6$ years). In the group with chronic non-transmissible diseases, the mean of $13.09 \pm 2.4$ was obtained for the physical domain, $13.75 \pm 2.5$ for the psychological domain, $13.04 \pm 3.1$ for the social domain and $13.71 \pm 2.3$ for the environment domain. In the healthy patient group, the means were $14.55 \pm 2.2$ for the physical domain, $14.45 \pm 2.0$ for the psychological domain, $14.39 \pm 2.2$ for the social domain and $14.07 \pm 1.9$ for the environment domain. Significant statistical differences were found between the chronic and non-chronic groups $(z=3.653, p<0.001)^{(11)}$. The WHOQOL-BREF was used to evaluate the QOL of 68 people diagnosed with Parkinson's disease, in which the overall quality of life presented a mean of 52.2 points, the mean of the physical domain was 54.5 , the psychological domain 62.0, the social domain 63.1, and for the environment domain the mean was $63.6^{(12)}$. The scores of the overall quality of life and of the four specific domains obtained in the present study, except for the social domain, were lower than those reported in similar studies $^{(10,12)}$, suggesting a lower QOL in clients with PAD in relation to those undergoing hemodialysis treatment and those with Parkinson's disease.

The revascularized clients who participated in an ethnographic study related their perception of QOL to the well-being, satisfaction and opportunities in life, with thematic issues "being healthy", "work" and "family harmony". The thematic issue "being healthy" was related to physical health, emotional health and spiritual health; the theme "work" was related to material well-being, to acquiring goods and to having money, the theme "family harmony" was related to the social environment(7).

The present study contributes to the complementation of the qualitative studies $^{(7)}$, because with the use a generic instrument for QOL evaluation, it was possible to establish quantitatively how the QOL can be influenced by the cardiovascular diseases.

\section{Final considerations}

It was found that clients with Peripheral Arterial Disease had the four domains of quality of life affected, most notably the physical domain, followed in descending order by the environment, psychological and social.

It was observed that most clients with PAD, presented the intensity of chronic pain with an mean of 5.59 points and mean values for quality of life between 44.75 and 68.33, which correspond to the physical and social domains, respectively.

The current study is presented as a scientific resource useful in clinical practice in health, as it indicates valid results concerning the evaluation of quality of life in clients with chronic ischemic pain, thereby contributing to improving the management of chronic ischemic pain and the quality of life.

\section{References}

1. Green DW, Sicard GA. Occlusive Arterial Disease. In: Klingensmith ME, Amos KD, Green, DW, Halpin, VJ, Hunt, SR, editors. Washington Manual of Surgery. 4. ed. Philadelphia (NJ): Lippincott Williams and Wilkins; 2005. p. 346-63.

2. Norgren L, Hiatt WR, Dormandy JA, Nehler MR, Harris KA, Fowkes FG; TASC II Working Group. Inter-society consensus for the management of peripheral arterial disease (TASC II). J Vasc Surg 2007; 45 Suppl S:S5-67.

3. Faleiros Sousa FAE, Da Silva JA. A métrica da dor (dormetria): problemas teóricos e metodológicos. Rev Dor. 2005;6(1):469-513.

4. Niv D, Kreitler S. Pain and quality of life. Pain Pract. 2001;1(2):150-61.

5. World Health Organization. World Health Organization supports global effort to relieve chronic pain. 2004 [acesso 14 ago 2010]. Disponível em: http://www.who. int/mediacentre/news/releases/2004/pr70/en/

6. World Health Organization. WHOQOL-Bref: Introduction, administration, scoring and assessment of the generic version-field trial version. 1996. [acesso 14 ago 2010]. Disponível em: http://www.who.int/mental_ health/media/en/76.pdf 
7. Vila VSC, Rossi LA. Quality of life from the perspective of revascularized patients during rehabilitation: an ethnographic study. Rev. Latino-Am. Enfermagem. 2008;16(1):7-14.

8. Fleck MPA, Louzada S, Xavier M, Chachamovich E, Vieira G, Santos L, et al. Aplicação da versão em português do instrumento abreviado de avaliação da qualidade de vida "WHOQOL-bref". Rev Saúde Pública. 2000;34(2):178-83.

9. Pereira RJ, Cotta RMM, Franceschini SCC, Ribeiro RCL, Sampaio RF, Priore SE, et al. Contribuição dos domínios físico, social, psicológico e ambiental para a qualidade de vida global de idosos. Rev Psiquiatr Rio Gd. Sul. 2006;28(1):27-38.

10. Higa K, Kost MT, Soares DM, Morais MC, Polins BRG. Qualidade de vida de pacientes portadores de insuficiência renal crônica em tratamento de hemodiálise. Acta Paul. Enferm. 2008; 21(esp.):203-6.

11. Morales AU, Esparcia AJ. Calidad de vida y estilos de afrontamiento en personas con patologías crônicas. Rev Interam Psicol. 2008;42(1):151-60.

12. Hirayama MS, Gobbi S, Gobbi LTB, Stella F. Quality of life (QoL) in relation to disease severity in Brazilian Parkinson's patients as measured using the WHOQOLBREF. Arch Gerontol Geriatr. 2008;46(2):147-60. 